\title{
Informed choice in infant feeding decisions can be supported for HIV-infected women even in industrialized countries
}

\author{
Pamela Morrison $^{a}$, Kiersten Israel-Ballard ${ }^{b}$ and Ted Greiner ${ }^{c}$
}

AIDS 2011, 25:1807-1811

Keywords: breastfeeding, HIV, infant feeding choice

Following the first report of HIV transmission through breast milk in 1985 [1], the US Centers for Disease Control issued a recommendation against breastfeeding by HIV-infected mothers [2]. In the last 25 years, prevention strategies in industrialized countries have evolved to reduce the risk of mother-to-child transmission (MTCT) of HIV to approximately 1-2\% [3] through routine prenatal HIV testing, maternal/infant antiretroviral prophylaxis/therapy (whichever is appropriate) (ART), Cesarean section and avoidance of all breastfeeding [4-6]. These recommendations for breastfeeding avoidance in industrialized countries were based on two fundamental assumptions: there was a high risk of breastfeeding-associated transmission and replacement feeding was safe in industrialized country settings $[7,8]$.

Over the next two decades, new research from lowincome countries (LICs) began to call into question the first of these assumptions, as noted in a recent review [9]. Exclusive breastfeeding, combined with effective maternal/infant ART was shown to greatly reduce breastfeeding transmission. By mid-2011 at least eight studies demonstrated that early and appropriate ART combined with exclusive breastfeeding for up to 6 months reduces the postnatal transmission risk to $0-1 \%$ (Table 1 ) [10-17]. In a recent, large study with extensive follow-up [15], no cases of postnatal transmission occurred among women adherent to ART. This body of evidence underpins new WHO guidelines [18].
Pasteurization of the HIV-infected mother's own breast milk is probably the safest option and deserves more attention than it currently receives. In industrialized countries, pasteurization options include single-bottle or commercial grade pasteurizers or flash-heating breast milk over a flame or stove, using a simple method of bringing a pan of water containing a glass bottle of breast milk to a boil. Even this simple home-based method of pasteurization deactivates both cell-free and cell-bound HIV, resulting in loss of infectivity, while maintaining breast milk's nutritional, antimicrobial and immunological properties $[19,20]$. In LICs, WHO recommends heat treatment as an interim strategy for safely providing breast milk to HIV-exposed infants unable to breastfeed, during maternal ill-health, to avoid high viremia during mastitis or premature weaning, or when ART is unavailable [18]. Several multicountry studies demonstrate the feasibility of HIV-infected mothers flash-heating substantial volumes of breast milk over 6 months $[21,22]$. Outside the context of HIV, pumping or manually expressing breast milk has been a common practice among employed mothers. Exclusively, breast milk-feeding a baby for 6 months or longer is also common for very low birth weight, extremely premature babies [23] as well as those with cleft palate or neurological disorders. Use of a breast pump may simplify the process.

Although the assumption that artificial feeding from birth is without risk in industrialized countries is still common

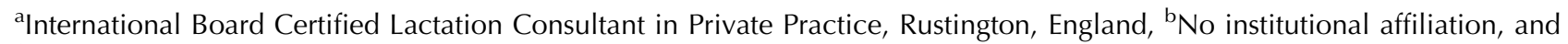
${ }^{\mathrm{c} C o l l e g e}$ of Human Ecology, Hanyang University, Seoul, South Korea.

Correspondence to Ted Greiner, PhD, Professor of Nutrition, College of Human Ecology, Hanyang University, 17 Haengdangdong, Seoul 133-791, South Korea.

Tel: +82 22220 1208; fax: +82 22292 1226; e-mail: tgreiner@hanyang.ac.kr, tedgreiner@yahoo.com Received: 12 March 2011; revised: 14 July 2011; accepted: 22 July 2011.
}

DOI:10.1097/QAD.0b013e32834b3519

ISSN 0269-9370 @ 2011 Wolters Kluwer Health | Lippincott Williams \& Wilkins Copyright @ Lippincott Williams \& Wilkins. Unauthorized reproduction of this article is prohibited. 


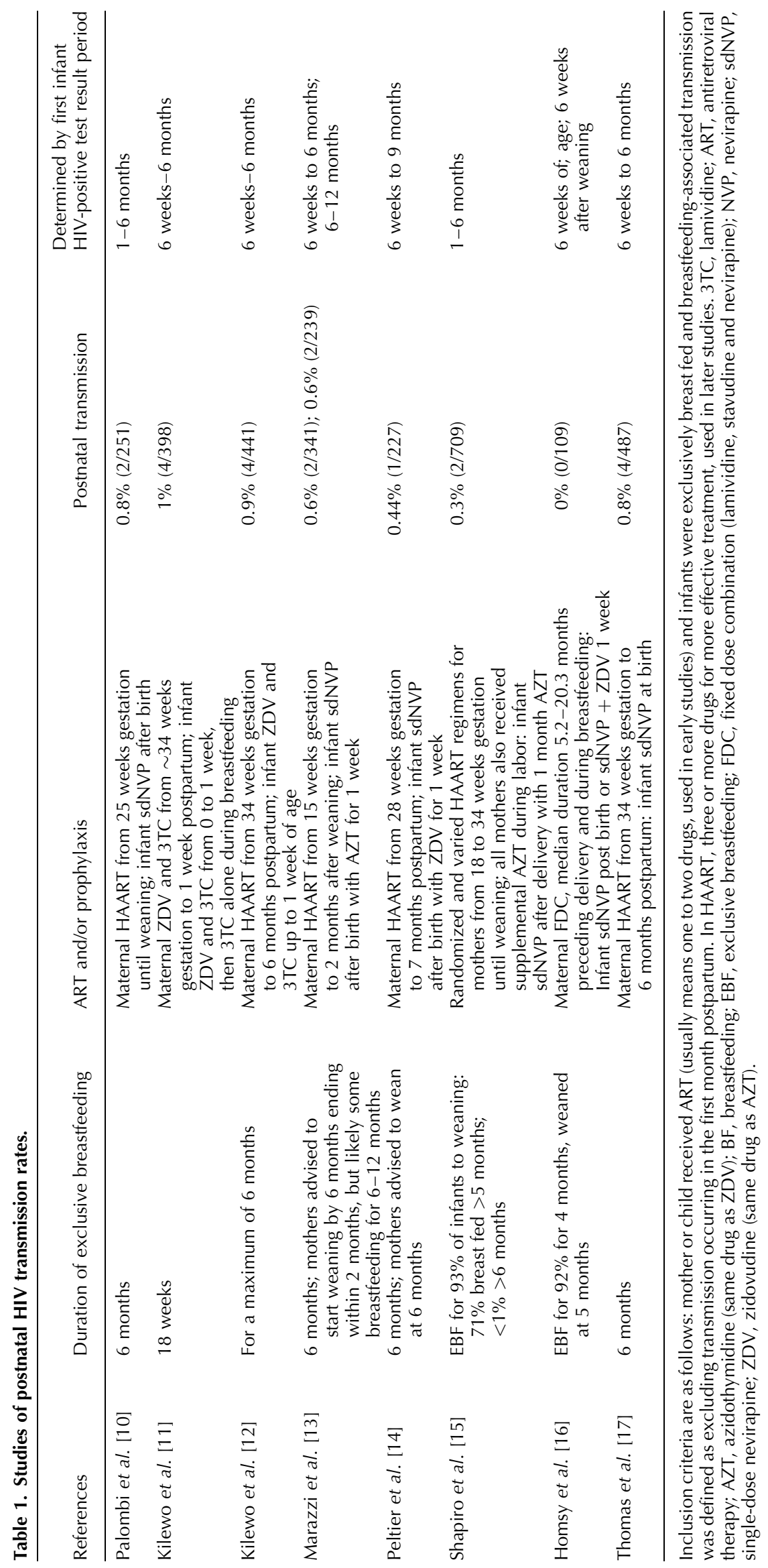


(strengthened by journal titles and abstracts that systematically fail to state findings in language that links artificial feeding to increased morbidity [24]) research has begun to call this belief into question. Although reliable estimates of an association between breastfeeding and mortality are difficult to arrive at [25], substantial evidence links formula-feeding with increased morbidity $[26,27]$ and mortality [28-30]. In the USA, conservative estimates of excess mortality due to suboptimal breastfeeding vary from 911 [29] to 720 [31] deaths per year, with approximately 400 being due to diarrhea alone [32]. Artificial feeding increases the risk of necrotizing enterocolitis and death among premature infants [33] and increases the risk for sudden infant death syndrome [34]. The UK Millennium Cohort Study [35] estimated that exclusive and sustained breastfeeding could prevent 53 and $27 \%$ of hospitalizations due to diarrheal and lower respiratory tract infections and partial breastfeeding could prevent 31 and 25\%, respectively.

HIV-infected women living in industrialized countries have exhibited varied responses to policies calling for them to artificially feed. In a 1999 US case, an HIVinfected pregnant mother who stated her intention to breastfeed lost legal custody of her infant and was granted physical custody only if she complied with a court order to formula-feed [36]. Other reports in the literature have described various steps taken to ensure that HIV-infected women do not breastfeed [37]. Although seen as a last resort [38], threats to remove a child from parental custody have been based on the assumption that breastfeeding represents a clear danger to the child.

In a recent Australian case, Walls et al. [39] describe their care of a clinically well, pregnant HIV-infected woman wishing either to breastfeed or provide her child with pasteurized expressed breast milk. The mother was receiving ART, had an undetectable viral load and a CD4 cell count of more than 500 cells $/ \mu 1$. Citing research showing considerable risk, including that 11 of ingested breast milk equates to one act of unprotected sex [40], the authors recommended formula-feeding, claiming a duty of care to protect the infant. To prevent breastfeeding, the case was ultimately referred antenatally to child protection services. Walls et al. also stated concerns that heat treatment of breast milk cannot be recommended due to its inconvenience. The evidence presented above was not cited, leading us to conclude that this was a poorly evidenced opinion that fails to justify threatening a mother with loss of custody of her child. They also expressed concern about the risk of 'mixed feeding.' However, as HIV is inactivated by heat treatment, thereby eliminating risk of transmission during possible mixed feeding, this too appears to be overcautious.

In the UK, there has been growing concern that such decades-old policies are inadequate. First, queries about the possibility of breastfeeding have been coming from
HIV-infected pregnant women already receiving ART and aware of new reports of low risk of MTCT through breastfeeding [41]. Second, between 2004 and 2006, $78.6 \%$ of HIV-positive mothers living in the UK were born in sub-Saharan Africa [42] where breastfeeding is simultaneously the cultural norm, a cornerstone of child survival and a valued traditional practice with important social implications. Strong family and peer pressure to breastfeed and the stigma attached to artificial feeding in their home countries, which may identify them as HIVinfected [43-45], are among factors motivating these mothers. Implementation of such a no-breastfeeding policy may be particularly inappropriate for failed asylum-seekers repatriated to LICs with sufficient infant formula only for the flight home [46], leaving their babies' food security at considerable risk. In such settings, recent research has found an inability to provide safe bottle feeds even among mothers with a high school education and a refrigerator at home [47].

In view of these concerns, the British HIV Association and the Children's HIV Association jointly undertook a wide consultation and revision of infant feeding guidance for British HIV-infected mothers, which was formally published in March 2011 [48]. Although recommending formula-feeding for most HIV-infected mothers, this new guidance recognizes that a woman on effective triple ART, with a repeated undetectable viral load at delivery may, after careful consideration, choose to exclusively breastfeed for the first 6 months of her baby's life. It points out the need for frequent follow-up, careful monitoring of maternal ART adherence until 1 week after weaning and monthly checks on maternal viral load and infant HIV status.

An analogous public health dilemma has existed around Cesarean section recommendations for HIV-infected mothers. Recent data demonstrate that ART during pregnancy results in an extremely low risk of MTCT during labor. Given the lack of clear evidence of benefit for elective Cesarean section [49], British HIV-infected women with a viral load less than 50 copies $/ \mathrm{ml}$ are now able to choose vaginal delivery [50].

Similarly, we would argue that data lacking when industrialized country policies on HIV and infant feeding were formulated in the 1980s concerning, first, the extremely low risk of postnatal HIV transmission for women receiving appropriate ART with resulting undetectable viremia, second, the safety and feasibility of heat treatment of expressed breast milk and, third, the mortality risk of breastfeeding avoidance in industrialized countries argue for a rethinking of HIV and infant feeding policies in other industrialized countries. Following the British precedent, when appropriate preconditions exist, HIV-infected women should be supported in making informed infant feeding choices. We hope this article will help initiate discussions and that such changes in policy will be followed by continued research on all three of the 
issues listed above. In particular, data on postnatal transmission are based only on efficacy trials and data on effectiveness under real-life conditions are also needed. In addition, we know too little still about the long-term effects of providing ART to healthy mothers or infants nor how well mothers will comply with such regimes over longer periods of breastfeeding.

\section{Acknowledgements}

T.G. researched and wrote on the risks of artificial feeding, P.M. on breastfeeding in the context of HIV and K.I.-B. on the issue of heat treatment. P.M. and T.G. did most of the writing of this article. No financial support of any kind was provided to the authors for the writing of this manuscript.

\section{Conflicts of interest}

The authors declare that they have no conflicts of interest.

\section{References}

1. Ziegler JB, Johnson RO, Cooper DA, Gold J. Postnatal transmission of AIDS-associated retrovirus from mother to infant. Lancet 1985: 1:896-898.

2. Centers for Disease Control and Prevention. Recommendations for assisting in the prevention of perinatal transmission of human T lymphotropic virus type III/lymphadenopathy-associated virus and acquired immunodeficiency syndrome. MMWR Morb Mortal Wkly Rep 1985; 34:721-726, 731-732.

3. Townsend C, Cortina-Borja M, Peckham C, Tookey P. Trends in management and outcome of pregnancies in HIV-infected women in the UK and Ireland, 1990-2006. BJOG 2008; 11:1078-1086.

4. Socialstyrelsen. The Social Welfare Board's Directive on the use of breast milk etc [in Swedish]. Stockholm: Welfare NBoHa; 1987.

5. National Health \& Medical Research Council, Dietary Guidelines for Children and Adolescents in Australia incorporating the Infant Feeding Guidelines for Health Workers. Commonwealth of Australia 2003. Australian National Health \& Medical Research Council. Infant feeding guidelines for Health Workers; 2002. http://www.nhmrc.gov.au/_files_nhmrc/ publications/attachments/n34.pdf?q= publications/synopses/_files/n34.pdf

6. American Academy of Pediatrics. Breastfeeding and the use of human milk. Policy statement: organizational principles to guide and define the child healthcare system and/or improve the health of all children (2005 revision). Pediatrics 2005; 115:496-506.

7. Dunn D, Newell M, Ades A, Peckham C. Risk of human immunodeficiency virus type 1 transmission through breastfeeding. Lancet 1992; 340:585-588.

8. De Cock KM, Fowler MG, Mercier E, de Vincenzi I, Saba J, Hoff $\mathrm{E}$, et al. Prevention of mother-to-child HIV transmission in resource-poor countries: translating research into policy and practice. JAMA 2000; 283:1175-1182.

9. Kuhn L, Aldrovandi G. Survival and health benefits of breastfeeding versus artificial feeding in infants of HIV-infected women: developing versus developed world. Clin Perinatol 2010; 37:843-862.

10. Palombi L, Marazzi MC, Voetberg A, Magid NA; the DREAM Program Prevention of Mother-to-Child Transmission Team. Treatment acceleration program and the experience of the DREAM program in prevention of mother-to-child transmission of HIV. AIDS 2007; 21 (Suppl 4):S65-S71.
11. Kilewo C, Karlsson K, Massawe A, Lyamuya E, Swai A, Mhalu F, et al. Prevention of mother-to-child transmission of HIV-1 through breast-feeding by treating infants prophylactically with lamivudine in Dar es Salaam, Tanzania: the Mitra Study. J Acquir Immune Defic Syndr 2008; 48:315-323.

12. Kilewo C, Karlsson K, Ngarina M, Massawe A, Lyamuya E, Swai A, et al. Prevention of mother to child transmission of HIV-1 through breastfeeding by treating mothers with triple antiretroviral therapy in Dar es Salaam, Tanzania: the Mitra Plus study. J Acquir Immune Defic Syndr 2009; 52:406-416.

13. Marazzi MC, Nielsen-Saines $K$, Buonomi PE, Scarcella $P$, Germano P, Majid NA, et al. Increased infant human immunodeficiency virus-type one free survival at one year of age in subSaharan Africa with maternal use of highly active antiretroviral therapy during breast-feeding. Pediatr Infect Dis / 2009; 28:483487.

14. Peltier CA, Ndayisaba GF, Lepage $P$, van Griensven J, Leroy $\mathrm{V}$ Pharm $\mathrm{CO}$, et al. Breastfeeding with maternal antiretroviral therapy or formula feeding to prevent HIV postnatal mother-to child transmission in Rwanda. AIDS 2009; 23:2415-2423.

15. Shapiro RL, Hughes MD, Ogwu A, Kitch D, Lockman S, Moffat $\mathrm{C}$, et al. Antiretroviral regimens in pregnancy and breastfeeding in Botswana. N Engl / Med 2010; 362:2282-2294.

16. Homsy J, Moore D, Barasa A, Were W, Likicho C, Waiswa B, et al. Breastfeeding, mother-to-child HIV transmission, and mortality among infants born to HIV-infected women on highly active antiretroviral therapy in rural Uganda. J Acquir Immune Defic Syndr 2010; 53:28-35.

17. Thomas TK, Masaba R, Borkowf CB, Ndivo R, Zeh C, Misore A, et al. Triple-antiretroviral prophylaxis to prevent mother-tochild HIV transmission through breastfeeding: the Kisumu Breastfeeding Study, Kenya - a clinical trial. PLOS Med 2011; 8:e1001015.

18. World Health Organization. Guidelines on HIV and infant feeding. Geneva: WHO Press; 2010. http://www.who.int/child_ adolescent health/documents/9789241599535/en/index.html.

19. Israel-Ballard KA, Abrams BF, Coutsoudis A, Sibeko LN, Cheryk LA, Chantry CJ. Vitamin content of breast milk from HIV-1. infected mothers before and after flash-heat treatment. J Acquir Immune Defic Syndr 2008; 48:444-449.

20. Volk ML, Hanson CV, Israel-Ballard K Chantry CJ. Inactivation of cell-associated and cell-free HIV-1 by flash-heat treatment of breast milk. J Acquir Immune Defic Syndr 2010; 53:665-666.

21. Young SL, Chantry C, Ngonyani M, Israel-Ballard K, Ash D, Nyambo M. Flash-heating breastmilk is feasible in Dar es Salaam Tanzania. Bangkok: IUNS International Congress of Nutrition; 2009.

22. Mbuya M, Humphrey J, Majo F, Chasekwa B, Jenkins A, IsraelBallard K, et al. Heat treatment of expressed breast milk is a feasible option for feeding HIV-exposed, uninfected children after 6 months of age in rural Zimbabwe. / Nutr 2010; 140:1481-1488.

23. Furman L, Minich NM, Hack M. Breastfeeding of very low birth weight infants. J Hum Lact 1998; 14:29-34.

24. Smith J, Dunstone M, Elliott-Rudder M. Health professional knowledge of breastfeeding: are the health risks of infant formula feeding accurately conveyed by the titles and abstracts of journal articles? J Hum Lact 2009; 25:350-358.

25. Golding J, Emmett PM, Rogers IS. Breast feeding and infant mortality. Early Hum Dev 1997; 49 (Suppl):S143-S155.

26. Bachrach VR, Schwarz E, Bachrach LR. Breastfeeding and the risk of hospitalization for respiratory disease in infancy: a metaanalysis. Arch Pediatr Adolesc Med 2003; 157:237-243.

27. Ladomenou F, Moschandreas J, Kafatos A, Tselentis Y, Galanakis $E$. Protective effect of exclusive breastfeeding against infections during infancy: a prospective study. Arch Dis Child 2010; 95:1004-1008

28. Ip S, Chung M, Raman G, Trikalinos TA, Lau J. A summary of the Agency for Healthcare Research and Quality's evidence report on breastfeeding in developed countries. Breastfeed Med 2009; 4:S17-30.

29. Bartick M, Reinhold A. The burden of suboptimal breastfeeding in the United States: a pediatric cost analysis. Pediatrics 2010; 125:e1048-e1056.

30. Duijts L, Jaddoe VW, Hofman A, Moll HA. Prolonged and exclusive breastfeeding reduces the risk of infectious diseases in infancy. Pediatrics 2010; 126:e18-25.

31. Chen A, Rogan WJ. Breastfeeding and the risk of postneonatal death in the United States. Pediatrics 2004; 113:e435-e439. 
32. Glass RI, Lew JF, Gangarosa RE, Lebaron CW, Ho MS. Estimates of morbidity and mortality-rates for diarrheal diseases in American children. J Pediatr 1991; 118:S27-S33.

33. Lambert DK, Christensen RD, Henry E, Besner GE, Baer VL, Wiedmeier $\mathrm{SE}$, et al. Necrotizing enterocolitis in term neonates: data from a multihospital health-care system. J Perinatol 2007; 27:437-443.

34. Vennemann MM, Bajanowski T, Brinkmann B, Jorch $G$, Yücesan $\mathrm{K}$, Sauerland $\mathrm{C}$, et al. Does breastfeeding reduce the risk of sudden infant death syndrome? Pediatrics 2009; 123:e406-e410.

35. Quigley MA, Kelly YJ, Sacker A. Breastfeeding and hospitalization for diarrheal and respiratory infection in the United Kingdom Millennium Cohort Study. Pediatrics 2007; 119:E837-E842.

36. Kent G. Tested in court: the right to breastfeed. SCN News. Vol. 18; July 1999. pp. 89-90.

37. Wolf LE, Lo B, Beckerman KP, Dorenbaum A, Kilpatrick SJ, Weintrub PS. When parents reject interventions to reduce postnatal human immunodeficiency virus transmission. Arch Pediatr Adolesc Med 2002; 155:927-933.

38. WHO Regional Office for Europe, UNFPA, UNAIDS, UNICEF. Strategic framework for the prevention of HIV infection in infants in Europe. Copenhagen: WHO Regional Office for Europe; 2004. http://www.unicef.org/ceecis/Strategic_framework_for_the_prevention_of_HIV.pdf.

39. Walls T, Palasanthiran, Studdert J, Moran K, Ziegler JB. Breastfeeding in mothers with HIV. I Paediatr Child Health 2010; 46:349-352.

40. Richardson BA, John-Stewart GC, Hughes JP, Nduati R, MboriNgacha D, Overbaugh J, Kreiss JK. Breast-milk infectivity in human immunodeficiency virus type 1-infected mothers. J Infect Dis 2003; 187:736-740.

41. Tudor-Williams G. Changing UK practice: influence from resource-poor setting, including new infant feeding guidance, Plenary Session 3, Thursday 22nd April 2010 (Afternoon), Second Joint Conference of the British HIV Association (BHIVA) and the British Association for Sexual Health and HIV (BASHH), Imperial College London-Manchester Central Convention Complex April 20-23, 2010. http://www.bhiva.org/100422Gareth_ Tudor_Williams.aspx
42. Conway M. Children HIV asylum and immigration. London: Children's HIV Association; 2006. http://www.chiva.org.uk/ publications/2006/pdf/childrenandasylum06.pdf.

43. Doherty T, Chopra M, Nkonki L, Jackson D, Greiner T. Effect of the HIV epidemic on infant feeding in South Africa: 'when they see me coming with the tins they laugh at $\mathbf{m e}^{\prime}$. Bull WHO 2006; 84:90-96.

44. Thairu L, Pelto G, Rollins N, Bland R, Ntshangase N. Sociocultural influences on infant feeding decisions among HIVinfected women in rural Kwa-Zulu Natal, South Africa. Matern Child Nutr 2005; 1:2-10.

45. De Paoli M, Manongi R, Klepp-F K-I. Factors influencing acceptability of voluntary counselling and HIV-testing among pregnant women in northern Tanzania. AIDS Care 2004; 16:411-425

46. Aynsley-Green A. The Childrens Commissioner for England's follow up report to the arrest and detention of children subject to immigration control. London: 11 Million; 2010. http://www. childrenscommissioner.gov.uk/force download.php? $\mathrm{f} p=\% 2$ Fclient_assets $\% 2$ Fcp $\% 2$ Fpublication $\% 2$ F394\%2FYarls_Wood_ report_Feb_2010_-_Executive_summary.pdf.

47. Andresen E, Rollins NC, Sturm AW, Conana N, Greiner T. Bacterial contamination and over-dilution of commercial infant formula prepared by HIV-infected mothers in a prevention of mother-to-child transmission (PMTCT) programme, South Africa. J Trop Pediatr 2007; 53:409-414.

48. Taylor GP, Anderson J, Clayden P, Gazzard BG, Fortin J, Kennedy J, et al. British HIV Association and Children's HIV Association position statement on infant feeding in the UK. HIV Med 2011; 12:389-393.

49. Wax JR. Maternal request cesarean versus planned spontaneous vaginal delivery: maternal morbidity and short term outcomes. Semin Perinatol 2006; 30:247-252.

50. de Ruiter A, Mercey D, Anderson J, Chakraborty R, Clayden P, Foster G, et al. British HIV Association and Children's HIV Association guidelines for the management of HIV infection in pregnant women. HIV Med 2008; 9:452502. 